\title{
DEPRESSION IN DISSOCIATIVE (CONVERSION) DISORDER PATIENTS;
}

In a Tertiary Care Teaching Hospital.

\section{Dr. Saeed Akhtar, Asia Manzoor, Dr. Azra Yasmeen}

ABSTRACT... Objective: Prevalence of depression in Dissociative (Conversion) disorder Patients. Place and Duration of Study: The study was conducted in the Department of Psychiatry \& Behavioural Science / Bahawal Victoria Hospital \& Quaid-e-Azam Medical College, Bahawalpur, from February 2012 to May 2012. Subjects and Methods: The sample consisted of 100 consecutive in patients (Female 84, Male 16) of Dissociative (Conversion) disorder. They were interviewed and results were analyzed from the entries in a Performa and Hamilton Rating Scale for Depression. Results: Majority of the patients were female (84\%), uneducated (54\%) and unmarried (60\%). Mean age of our patients was $21.84 \pm 7.29$ years. Depression was found in $76 \%$ of patients. Out of 76 depressed patients had moderate depression, 24 had severe depression. Conclusions: Our study collaborates that depression was present in high proportion in patients with dissociative (conversion) disorder, which shows that co-morbid depression should not be over looked in these patients. It is recommended that every patient presenting with dissociative (Conversion) disorder should be assessed for co-morbid depression and should be managed accordingly.

Key words: Depression, Dissociative Disorder, Hamilton Rating

Article Citation

Akhtar S, Manzoor A, Yasmeen A. Depression in dissociative (conversion) disorder patients; In a Tertiary Care Teaching Hospital. Professional Med J 2013;20(2): 272-278.

\section{INTRODUCTION}

Conversion disorder is linked historically to the concept of hysteria. In DSM-III and its subsequent versions, dissociative disorder has been considered a separate group. On the other hand, the latest version of the International Classification of disease, the ICD-10, put all manifestation of hysterical neurosis under the rubric of dissociative disorders. This is in accordance with the findings of modern studies that have revived evidence for the relationship between somatoform symptoms and dissociation ${ }^{1-3}$.

Conversion Disorder contributes a major proportion of psychiatric patient population in developing countries $^{4}$. Despite the fact that its incidence have been decreasing in western countries ${ }^{5}$. The epidemiological studies conducted in India have found the prevalence to be $31 \%$ among in hospitalized children and adolescents ${ }^{6}$. In Turkey the prevalence of dissociative disorder in a semirural area was found to be $27.2 \%$. Various studies reported from Pakistan showed that Dissociative Disorder still account for up to $10 \%$ of admissions in psychiatric facilities ${ }^{5}$.
Patients with Conversion Disorder have overall psychiatric symptoms scores close to those of general psychiatric patients ${ }^{2}$, suggesting high psychiatric co-morbidity. As in most psychiatric disorders, co-morbidity is frequently found in dissociative disorder ${ }^{8}$. Several studies have shown that anxiety, depression and panic disorder are the most commonly occurring co-morbidity disorders with dissociative disorder ${ }^{9,10}$.

Mazhar Malik's study at Fauji Foundation Hospital Rawalpindi showed substantially high rates of depression (61\%) in conversion disorder patients ${ }^{11}$. In a study carried out by Khattak $T$, it was found that depression was present in $73 \%$ of patients with dissociative disorder ${ }^{12}$, and more recent study quotes $84 \%$ of patients had depression with dissociative disorder ${ }^{13}$.

The aim of this study was to determine the frequency of depression in dissociative (Conversion) disorder patients presenting to a Tertiary Care Facility, B.V Hospital Bahawalpur. 


\section{PATIENTS AND METHODS}

This descriptive cross sectional study was carried out in the Department of Psychiatry of B.V Hospital, Bahawalpur, a tertiary care facility. 100 consecutive in patients of both sexes between ages of 13-50 years, diagnosed as conversion disorder from February 2012 to May 2012 were included in the study. The diagnosis was based on the criteria laid down by ICD-10 (International Classification of mental disorder, $10^{\text {th }}$ edition). The patients suffering from physical illnesses, organic brain disease, psychiatric co-morbidity other than depression, substance abuse, learning disability, those having language barrier, those who refused to participate in the study, were excluded from the study. Participating patients underwent detailed assessments which included a consent form, physical examination, demographic profile, ICD-10 criteria of Dissociative (Conversion) disorder and the Hamilton Rating Scale for Depression. The data was entered in to SPSS version 16. Mild, Moderate, Sever \& Very Severe, types of depression were presented in the form of frequencies.

\section{RESULTS}

During the study period 100 patients were recruited. The mean age was $21.84 \pm 7.29$ years.

Most of the patients (84\%) were female.

$54 \%$ were uneducated and the rest had an education from primary to B.A level.

Married patients constituted $40 \%$ while $60 \%$ were not married.

The data was analyzed for co-morbid depression. The patients who had clinical depression were 76\% (76 patients) and their mean score was 21.26.

24\% (24 patients) were not depressed and their mean score was 3.83. The difference in mean score (-17.42) between the depressed and non depressed group was

\begin{tabular}{|c|c|c|c|c|c|}
\hline & & & Age & & \\
\hline & & Frequency & Percent & \begin{tabular}{|l} 
Valid \\
Percent
\end{tabular} & $\begin{array}{c}\text { Cumulative } \\
\text { ercent }\end{array}$ \\
\hline & 13 & 2 & 2.0 & 2.0 & 2.0 \\
\hline & 14 & 4 & 4.0 & 4.0 & 6.0 \\
\hline & 15 & 10 & 10.0 & 10.0 & 16.0 \\
\hline & 16 & 2 & 2.0 & 2.0 & 18.0 \\
\hline & 17 & 4 & 4.0 & 4.0 & 22.0 \\
\hline & 18 & 26 & 26.0 & 26.0 & 48.0 \\
\hline . & 19 & 2 & 2.0 & 2.0 & 50.0 \\
\hline & 20 & 14 & 14.0 & 14.0 & 64.0 \\
\hline & 21 & 2 & 2.0 & 2.0 & 66.0 \\
\hline Valid & 24 & 2 & 2.0 & 2.0 & 68.0 \\
\hline & 25 & 12 & 12.0 & 12.0 & 80.0 \\
\hline & 26 & 2 & 2.0 & 2.0 & 82.0 \\
\hline & 27 & 2 & 2.0 & 2.0 & 84.0 \\
\hline & 30 & 4 & 4.0 & 4.0 & 88.0 \\
\hline & 32 & 2 & 2.0 & 2.0 & 90.0 \\
\hline & 33 & 2 & 2.0 & 2.0 & 92.0 \\
\hline & 35 & 4 & 4.0 & 4.0 & 96.0 \\
\hline & 45 & 4 & 4.0 & 4.0 & 100.0 \\
\hline & Total & 100 & 100.0 & 100.0 & \\
\hline
\end{tabular}

significant, $P$ value was less than 0.0001 , suggesting the presence of co-morbid depression. Out of 76 depressed patients, 8 had mild depression, 20 patients 


\begin{tabular}{|c|c|c|c|c|c|}
\hline \multicolumn{7}{|c|}{ Sex } \\
\hline \multirow{2}{*}{} & & Frequency & Percent & $\begin{array}{c}\text { Valid } \\
\text { Percent }\end{array}$ & $\begin{array}{c}\text { Cumulative } \\
\text { Percent }\end{array}$ \\
\hline \multirow{4}{*}{ Valid } & Female & 84 & 84.0 & 84.0 & 84.0 \\
\cline { 2 - 6 } & Male & 16 & 16.0 & 16.0 & 100.0 \\
\cline { 2 - 6 } & Total & 100 & 100.0 & 100.0 & \\
\hline \multirow{5}{*}{} & \multicolumn{5}{|c}{ Table-II. } \\
\end{tabular}

\begin{tabular}{|c|c|c|c|c|c|}
\hline \multicolumn{7}{|c|}{ Education } \\
\hline \multirow{4}{*}{ Valid } & Frequency & Percent & $\begin{array}{c}\text { Valid } \\
\text { Percent }\end{array}$ & $\begin{array}{c}\text { Cumulative } \\
\text { Percent }\end{array}$ \\
\cline { 2 - 6 } & Educated & 46 & 46.0 & 46.0 & 46.0 \\
\cline { 2 - 6 } & Uneducated & 54 & 54.0 & 54.0 & 100.0 \\
\cline { 2 - 6 } & Total & 100 & 100.0 & 100.0 & \\
\hline \multicolumn{5}{|c|}{ Table-III. } \\
\end{tabular}

\begin{tabular}{|c|c|c|c|c|c|}
\hline \multicolumn{7}{|c|}{ MARITAL } \\
\hline \multirow{2}{*}{ Frequency } & Percent & $\begin{array}{c}\text { Valid } \\
\text { Percent }\end{array}$ & $\begin{array}{c}\text { Cumulative } \\
\text { Percent }\end{array}$ \\
\hline \multirow{2}{*}{ Valid } & Married & 40 & 40.0 & 40.0 & 40.0 \\
\cline { 2 - 6 } & Unmarried & 60 & 60.0 & 60.0 & 100.0 \\
\cline { 2 - 6 } & Total & 100 & 100.0 & 100.0 & \\
\cline { 3 - 6 } & & \multicolumn{4}{|c}{ Table-IV. } \\
\hline
\end{tabular}

had moderate depression, 24 had severe depression and 24 patients had very severe depression.

Table no. VI, VII and VIII show the relationship of the demographic characteristics with the scores on rating scale for depression. The relationship of the demographic variables to the level of depression was

\begin{tabular}{|c|c|c|c|c|c|}
\hline \multicolumn{7}{|c|}{ Level } \\
\hline \multirow{7}{*}{ Valid } & Frequency & Percent & $\begin{array}{c}\text { Valid } \\
\text { Percent }\end{array}$ & $\begin{array}{c}\text { Cumulative } \\
\text { Percent }\end{array}$ \\
\hline \multirow{7}{*}{} & Mild & 8 & 8.0 & 8.0 & 8.0 \\
\cline { 2 - 6 } & Moderate & 20 & 20.0 & 20.0 & 28.0 \\
\cline { 2 - 6 } & Normal & 24 & 24.0 & 24.0 & 52.0 \\
\cline { 2 - 6 } & Severe & 24 & 24.0 & 24.0 & 76.0 \\
\cline { 2 - 6 } & $\begin{array}{c}\text { Very } \\
\text { Severe }\end{array}$ & 24 & 24.0 & 24.0 & 100.0 \\
\hline & Total & 100 & 100.0 & 100.0 & \\
\hline
\end{tabular}

also analyzed and there was no significant difference in the mean scores for depression between males and females, $P=0.74$. Similarly the difference in mean scores for depression for the uneducated and educated, the married and unmarried was not significant, the P-values for these variables were 0.74 and 0.33 respectively.

Number of depressed and un-depressed patients in different age groups are shown in table. no. IX.

And number of depressed and un-depressed patients in different profession are shown in the table no. $X$.

\section{DISCUSSION}

The demographic factors identified in this study revealed that majority of the patients were young females, uneducated and unmarried.

Female patients comprised $84 \%$ in our sample, other studies conducted by Tabassum Khattak, Uguzet et al and Sar et al reported figures of $88 \%, 87 \%$ and $80 \%$ respectively ${ }^{12,9,14}$. So proportion of female patients in our study is in broad agreement with other studies. In our study we found a large number of patients (60\%) 


\begin{tabular}{|c|c|c|c|c|c|c|}
\hline \multicolumn{5}{|c|}{ Level * Sex Crosstabulation } & & \\
\hline \multicolumn{2}{|c|}{ Count } & & & & & \\
\hline & & \multicolumn{2}{|c|}{ Sex } & \multirow{2}{*}{ Total } & $\%$ & $\%$ \\
\hline & & Female & Male & & Female & Male \\
\hline \multirow{5}{*}{ Level } & Mild & 6 & 2 & 8 & 75 & 25 \\
\hline & Moderate & 18 & 2 & 20 & 90 & 10 \\
\hline & Normal & 20 & 4 & 24 & 83 & 17 \\
\hline & Severe & 22 & 2 & 24 & 92 & 8 \\
\hline & $\begin{array}{l}\text { Very } \\
\text { Severe }\end{array}$ & 18 & 6 & 24 & 75 & 25 \\
\hline \multicolumn{2}{|c|}{ Total } & 84 & 16 & 100 & 84 & 16 \\
\hline
\end{tabular}

\begin{tabular}{|c|c|c|c|c|c|c|c|}
\hline \multicolumn{8}{|c|}{ Education * Level * Sex Crosstabulation } \\
\hline \multirow{2}{*}{\multicolumn{3}{|c|}{ Sex }} & \multicolumn{2}{|c|}{ Level } & \multirow{3}{*}{\begin{tabular}{|c|} 
Total \\
32 \\
\end{tabular}} & \multirow{3}{*}{$\begin{array}{c}\% \\
\text { Un } \\
\text { Dep. } \\
25\end{array}$} & \multirow{3}{*}{\begin{tabular}{|r|}
$\%$ \\
Dep \\
75 \\
\end{tabular}} \\
\hline & & & $\begin{array}{c}\text { Un } \\
\text { depressed }\end{array}$ & $\begin{array}{l}\text { Depr- } \\
\text { essed }\end{array}$ & & & \\
\hline \multirow{3}{*}{ Female } & \multirow{2}{*}{$\begin{array}{l}\text { Edu- } \\
\text { cation }\end{array}$} & Educated & 8 & 24 & & & \\
\hline & & $\begin{array}{c}\text { Un } \\
\text { educated }\end{array}$ & 12 & 40 & 52 & 23 & 77 \\
\hline & \multicolumn{2}{|c|}{ Total } & 20 & 64 & 84 & 24 & 76 \\
\hline \multirow{3}{*}{ Male } & \multirow{2}{*}{$\begin{array}{l}\text { Edu- } \\
\text { cation }\end{array}$} & Educated & 4 & 10 & 14 & 29 & 71 \\
\hline & & $\begin{array}{c}\text { Un } \\
\text { educated }\end{array}$ & 0 & 2 & 2 & 0 & 100 \\
\hline & \multicolumn{2}{|c|}{ Total } & 4 & 12 & 16 & 25 & 75 \\
\hline
\end{tabular}

who were single. Other studies also have reported a preponderance of single female patients e.g in a Turkish study $24 \%$ of patients were married and a Pakistani study revealed $33 \%$ married patients ${ }^{14,15}$.

Our study showed that high proportion of conversion

\begin{tabular}{|c|c|c|c|c|c|c|c|}
\hline \multicolumn{8}{|c|}{ MARITAL * Level * Sex Crosstabulation } \\
\hline \multirow{2}{*}{\multicolumn{3}{|c|}{ Sex }} & \multicolumn{2}{|c|}{ Level } & \multirow[b]{2}{*}{ Total } & \multirow{2}{*}{\begin{tabular}{|c}
$\%$ \\
$\begin{array}{l}\text { Undep- } \\
\text { ressed }\end{array}$
\end{tabular}} & \multirow{2}{*}{\begin{tabular}{|c|}
$\%$ \\
Depr- \\
essed
\end{tabular}} \\
\hline & & & Undep- & Depr- & & & \\
\hline \multirow{3}{*}{$\begin{array}{l}\text { Fe- } \\
\text { male }\end{array}$} & \multirow[b]{2}{*}{ MARITAL } & Married & 8 & 24 & 32 & 25 & 75 \\
\hline & & $\begin{array}{c}\text { Un- } \\
\text { married }\end{array}$ & 12 & 40 & 52 & 23 & 77 \\
\hline & \multicolumn{2}{|c|}{ Total } & 20 & 64 & 84 & 24 & 76 \\
\hline \multirow{3}{*}{ Male } & \multirow[b]{2}{*}{ MARITAL } & Married & 0 & 8 & 8 & 0 & 100 \\
\hline & & $\begin{array}{c}\text { Un- } \\
\text { married }\end{array}$ & 4 & 4 & 8 & 50 & 50 \\
\hline & \multicolumn{2}{|c|}{ Total } & 4 & 12 & 16 & 25 & 75 \\
\hline
\end{tabular}

\begin{tabular}{|c|c|c|c|c|c|c|c|}
\hline \multicolumn{8}{|c|}{ Age * Level * Sex Crosstabulation } \\
\hline \multirow{2}{*}{\multicolumn{3}{|c|}{ Sex }} & \multicolumn{2}{|c|}{ Level } & \multirow[b]{2}{*}{ Total } & \multirow{2}{*}{$\begin{array}{c}\% \\
\text { Undep- } \\
\text { ressed }\end{array}$} & \multirow{2}{*}{$\begin{array}{c}\% \\
\text { Depr- } \\
\text { essed }\end{array}$} \\
\hline & & & Undep- & Depr- & & & \\
\hline \multirow{5}{*}{$\begin{array}{l}\mathrm{Fe}- \\
\text { male }\end{array}$} & \multirow{4}{*}{ Age } & $13-20$ & 14 & 44 & 58 & 24 & 76 \\
\hline & & $21-30$ & 2 & 16 & 18 & 11 & 89 \\
\hline & & $31-40$ & 2 & 4 & 6 & 33 & 67 \\
\hline & & $41-50$ & 2 & 0 & 2 & 100 & 0 \\
\hline & \multicolumn{2}{|c|}{ Total } & 20 & 64 & 84 & 24 & 76 \\
\hline \multirow{5}{*}{ Male } & \multirow{4}{*}{ Age } & $13-20$ & 4 & 2 & 6 & 67 & 33 \\
\hline & & $21-30$ & 0 & 6 & 6 & 0 & 100 \\
\hline & & $31-40$ & 0 & 2 & 2 & 0 & 100 \\
\hline & & $41-50$ & 0 & 2 & 2 & 0 & 100 \\
\hline & \multicolumn{2}{|c|}{ Total } & 4 & 12 & 16 & 25 & 75 \\
\hline
\end{tabular}




\begin{tabular}{|c|c|c|c|c|c|c|c|}
\hline \multicolumn{8}{|c|}{ Profession * Level * Sex Crosstabulation } \\
\hline \multirow{2}{*}{\multicolumn{3}{|c|}{ Sex }} & \multicolumn{2}{|c|}{ Level } & \multirow{3}{*}{\begin{tabular}{c|} 
Total \\
10
\end{tabular}} & \multirow{3}{*}{$\begin{array}{c}\begin{array}{c}\text { Undep- } \\
\text { ressed }\end{array} \\
40\end{array}$} & \multirow{3}{*}{\begin{tabular}{|c|}
$\begin{array}{c}\text { Depr- } \\
\text { essed }\end{array}$ \\
60
\end{tabular}} \\
\hline & & & Undep- & Depr- & & & \\
\hline \multirow{7}{*}{$\begin{array}{c}\mathrm{Fe}- \\
\text { male }\end{array}$} & \multirow{6}{*}{$\begin{array}{l}\text { Pro- } \\
\text { fession }\end{array}$} & Embroidery & 4 & 6 & & & \\
\hline & & House Wife & 10 & 34 & 44 & 23 & 77 \\
\hline & & Stiching & 0 & 6 & 6 & 0 & 100 \\
\hline & & Student & 4 & 10 & 14 & 29 & 71 \\
\hline & & Tailoring & 2 & 6 & 8 & 25 & 75 \\
\hline & & Teaching & 0 & 2 & 2 & 0 & 100 \\
\hline & \multicolumn{2}{|r|}{ Total } & 20 & 64 & 84 & 24 & 76 \\
\hline \multirow{7}{*}{ Male } & \multirow{7}{*}{$\begin{array}{l}\text { Pro- } \\
\text { fession }\end{array}$} & Business & 0 & 2 & 2 & 0 & 100 \\
\hline & & Jeweler & 2 & 0 & 2 & 100 & 0 \\
\hline & & Labourer & 0 & 2 & 2 & 0 & 100 \\
\hline & & Shop Keeper & 0 & 2 & 2 & 0 & 100 \\
\hline & & Student & 2 & 0 & 2 & 100 & 0 \\
\hline & & Tailoring & 0 & 6 & 6 & 0 & 100 \\
\hline & & Total & 4 & 12 & 16 & 25 & 75 \\
\hline
\end{tabular}

disorder patients had clinically significant rate of depression. In this study (76) $76 \%$ of patients had depression which was supported by findings of study conducted with sample of 100 patients in Wah Cantt. According to which Anxiety and Depression was present in (74) $74 \%$ of patients ${ }^{16}$. Another study conducted with sample of 100 patients in Peshawar, according to which $73 \%$ had clinical depression. ${ }^{12}$ In another study of 20 psychiatric patients in Northern Ireland 13 out of 20 patients received diagnosis of dissociative disorder and all dissociative disorder patients $(n=13)$ had co-morbid depression ${ }^{17}$. In Rawalpindi General Hospital 50 patients of dissociative disorder were assessed and 42 (84\%) of them were found to have depression. ${ }^{13}$ Other studies also show the similar results ${ }^{9,18-21}$.

In contrast to the findings of studies mentioned above, a study by Sayeed et al, showed that only $29 \%$ of patients were suffering from clinical depression ${ }^{15}$.

The highs scores on depression and significantly high proportion of patients suffering from depression indicates that the majority of the patients presenting with dissociative (conversion) disorder have an under lying depressive illness. Inability of these patients, in presenting psychological symptoms of depression, results in presentation in the form of dissociative (conversion) disorder which receives more attention. So recognition and treatment of underlying depression needs to be considered for patients presenting with dissociative (conversion) disorder.

In view of the fact that conversion disorder is one of the commonest psychiatric disorder in our set up, there is need for further studies on the subject at community level. In particular the relationship of conversion disorder with depression needs to be explored in these studies.

\section{CONCLUSIONS}

Depression was present in high proportion that is in 76 (76\%) patients with dissociative (conversion) disorder, which shows that co-morbid depression should not be overlooked in these patients. Every patient presenting with dissociative (conversion) disorder should be assessed for co-morbid depression and should be managed accordingly.

\section{Copyright@ 11 Jan, 2013.}

\section{REFERENCES}

1. Saxe GN, Chinman G, Berkowitz R, Hall Kh, Lieberg G, Schwartz J, Van der kolk BA: Somatization in patients with dissociative disorders. Am J Psychiatry 1994; 
151; 1329-1334.

2. Spitzer C, Freyberger $\mathrm{H} \mathrm{J}$, Kessler C, K Ompf D: Psychiatrischekomorbibitaetdissoziativevstorungen in der neurologie (Psychiatric Comorbidity). Nervenarzt 1994; 65:680-688.

3. Nijenhuis ERS, Spinohven P, Van DyckR, Van der Hart O, Vander linden J: the development and Psychometric characteristics of the Somato form Dissociation Questionnaire (SD Q-20). J NervMent Dis 1996; 184: 688-694.

4. Kamala D, Pranit CK, Kavery B, Pranab K: Study of Clinical correlates and socio-demographic profile in conversion disorder. Indian J. Psychiatry 2007; 3 : 205-7.

5. Aamir S: Stressful life events in the onset of dissociative (conversion) disorders. J Pak Psych Soc 2005; 2: 65-8.

6. Malhi P, Singhi P: Clinical characteristics and outcome of children and adolescents with conversion disorder. Indian Pediatrics. 2002; 39: 747-52.

7. Sar V, Akyuz G, kundakci T, kizil tan E, Dogan 0: Childhood trauma, dissociation and psychiatric comorbidity in patients with conversion disorder. Am J Psychiatry 2004; 161: 2271-6.

8. Cloninger CR, Martin RL, Guze SB, Clay to PJ: A prospective follow-up and family study of somatization in men and women. Am J Psychiatry 1986; 143:873-78.

9. Uguz S, toros F: Socio demographic and clinical characteristics of patients with conversion disorder. Turk PsikiyatriDerg. 2003; 14:51-8.

10. Sagduyu A, Rezaki M, Kaplan I, Ozgen G, Rezaki B: Prevalence of conversion symptoms in a primary health care center. Turk psikiyatriDergisi 1997; 8: 16169.

11. Mazhalr Malik, Fatima Bilal, Sajida Kazmi Farkhanda Jabeen: Depression and anxiety in dissociative (conversion) disorder patients of a tertiary care Psychiatric facility. RMJ. 2010; 35(2): 224-226.
12. Khattak T: Socio demographic features affective symptoms and family functioning in hospitalized patients with dissociative disorder (convulsion type). J. Pak Med Assoc 2007; 57: 23-6.

13. Alvi T, Minhas FA: Type of presentation of dissociative disorder and frequency of co-morbid depressive disorder. J Coll physicians Surg Pak 2009; 19: 113-6.

14. Sar V, kundakci T, kiziltan E, Bakim B, Bozkurt O: Differentiating dissociative disorders from other diagnostic group through somatoform dissociation in Turkey. J Trauma and dissociation 2000; 1:67-80.

15. Sayeed MN, Ahmad S, Arshad N, Naeemullah, Maqsood N: Anxiety and depression symptoms in patients with conversion disorder. J CollPhySurg 2005; 15: 489-92.

16. Tabassum Alvi, Fatima Asad: Presentation and Psychiatric Co-morbidity in patients presenting with dissociative disorders. JPPS 2011; 8(1):18-21.

17. Dorahy MJ, Mills H, Taggart C, Kane MO: do Dissociative disorders exist in Northern Ireland? Blind psychiatric structured interview assessments of 20 complex psychiatric patients. Eur J Psychiatr 2006; 20: 172-82.

18. Sar V, Akyuz G, Doan 0: Prevalence of dissociative disorders among women in the general population. Psychiatry Res 2007; 149: 169-76.

19. Stone J, Warlow C, Sharpe M: The symptoms of functional weakness, a controlled study of 107 patients. Brain 2010; 133:1537-51.

20. Seritan Al, Schneider A, Olichney JM, Leehey MA, Akins $\mathrm{RS}$, Hagerman RJ: Conversion disorder in women with FMRI permutation. Am J Med G enet 2009; 149:2501-6

21. Marchetti RL, Kurcgant D, GallucciNeto, Von Bismark $M A$, Fiore LA: Evaluating patients with suspected nonepiloptic psychogenic seizures: J Neuro psychiatry Clin Neuro Sci 2009; 21: 292-8. 


\section{AUTHOR(S):}

1. DR. SAEEDAKHTAR, MBBS, MCPS, FCPS

Assistant Professor Department of Psychiatry

Bahawal Victoria Hospital,

Quaid-e-Azam Medical College, Bahawalpur.

2. ASIA MANZOOR, M.SC, ADCP

Clinical Psychologist Department of Psychiatry,

Bahawalpur Victoria Hospital, Bahawalpur.

3. DR. AZRAYASMEEN, MBBS, FCPS-I

Department of Obstetrics \&Gynecology,

Bahawal Victoria Hospital, Bahawalpur.

\section{Correspondence Address: \\ Dr. Saeed Akhtar \\ Residence: 21-C, Quaid-e-Azam Medical Colony, \\ Bahawalpur. \\ saeed.akhtar.dr@gmail.com}

\section{PREVIOUS RELATED STUDIES}

Khalid Hayat Khan, M. H. Tahir. DEPRESSION AMONGST EPILEPTIC PATIENTS (Original) Prof Med Jour 12(3) 317-321 Jul, Aug, Sep 2005.

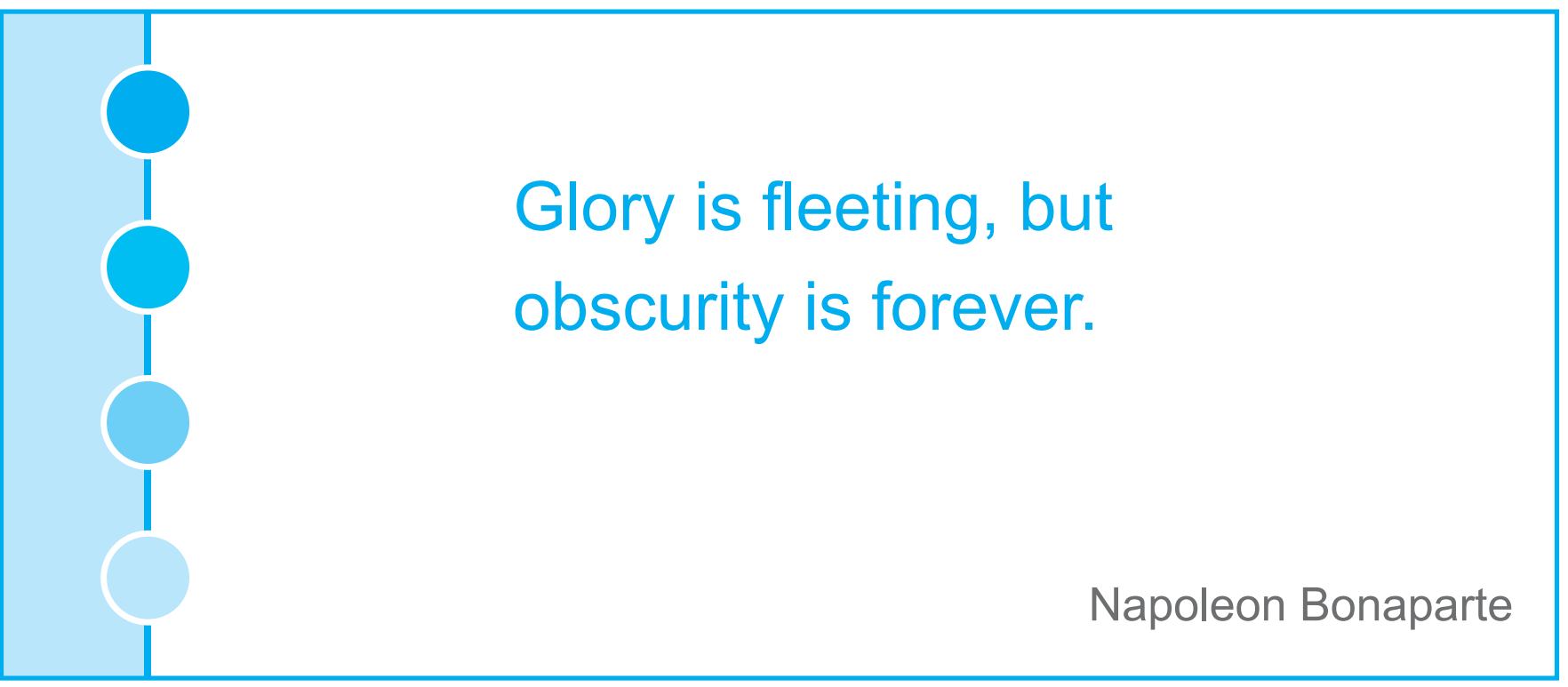

